\title{
SCREENING AND VACCINATION AGAINST HEPATITIS A IN PEDIATRIC CHRONIC LIVER DISEASE PATIENTS
}

\author{
Rajesh Kumar
}

Senior Lecturer, Dept. of Hepatogastroenterology, SIUT, Pakistan. Email: mandhwani.rajesh@gmail.com

\begin{abstract}
Background: Superadded HAV infection in patients with chronic liver disease (CLD) or cirrhosis may result in further deterioration of liver functions causing acute on chronic liver failure. The Center for disease control (CDC) strongly recommends to vaccinate all CLD patients against HAV.

Methods: All pediatric patients with chronic liver disease for $>6$ months, after informed consent from their parents were enrolled. HAV immunity was defined as the qualitative presence of HAV IgG antibody (?1.00 reactive) in the serum blood test. All patients with negative HAV IgG were subjected to HAV vaccination and adverse events were also noted.

Results: A total of 30 pediatric CLD patients with a mean age of $9.3 \pm 3.9$ years were enrolled. Majority of participants were males $n=19(63.3 \%)$. The overall prevalence of positive HAV serology (lgG) was $86.7 \%$. Three participants with negative HAV serology received a series of two vaccines, 6 months apart and HAV IgG titers were checked at 4 weeks after the first and second dose of vaccination. Despite two doses of vaccine satisfactory titer levels could not be achieved.
\end{abstract}

Conclusion: This is the first study from Pakistan in which pediatric CLD patients were evaluated for HAV exposure. Early vaccination is advisable in such patients as advanced liver disease patients may not achieve adequate titers.

Keywords: Hepatitis A; prevention; vaccination; chronic liver disease

\section{Introduction}

Hepatitis A virus (HAV) is a single-stranded RNA virus \& non-enveloped virus of Picornaviridae family. Due to lack of outer lipid layer, this virus is thermostable and resistant to lysis acid and bile which facilitates its fecooral transmission.1 Thus HAV infection is more prevalent in those countries with a lower socioeconomic status and having poor hygienic conditions1.

Pakistan is an endemic area for HAV infection, about 96 $\%$ of our general population is exposed to HAV by 5 years of age.2 HAV infection is often asymptomatic in early childhood which results in its lifelong immunity. However, this infection may result into severe infection and/or fulminant liver failure in adulthood and elderly people. It is also observed that superadded HAV infection in patients with chronic liver disease (CLD) or cirrhosis may result in further deterioration of liver function causing acute on chronic liver failure.3,4 It is suggested that Hepatitis B or C related CLD patients infected with HAV, have a more severe disease than those who do not have these viral infections. The case fatality rate of HAV infection was fivefold higher in patients with HBsAg carriers. 1
HAV infection is a preventable disease and can be curtailed by implementing certain measures such as providing safe drinking water, proper sewage disposal and improving personal hygiene. Furthermore HAV vaccination is another and more effective way of preventing Hepatitis A 4. Therefore, the center for disease control (CDC) strongly recommends to vaccinate CLD patients against HAV.5 Because of high endemicity of HAV in third world countries the utility of $H A V$ vaccine is controversial and hence its use needs to be justified by doing seroprevalence studies.

Currently there are very few studies on the seroprevalence of HAV amongst the pediatric CLD patients, hence we planned to check the seroprevalence of anti HAV antibodies ( $\operatorname{lgG}$ ) in the pediatric CLD patients and to vaccinate them if found negative serology for HAV.

\section{Methodology}

This study was conducted at the outpatients' Department of the Hepatogastroenterology Unit, Sindh Institute of Urology and Transplantation (SIUT), Karachi, Pakistan over a period of six months, from June 2016 to November 2016. All pediatric patients known to 
have liver disease for more than six months (CLD) were enrolled in this study after obtaining informed consent from their parents. A brief history was taken regarding the cause of CLD, family history of hepatitis, source of drinking water and consumption of street food. A blood sample was drawn for complete blood count, creatinine, albumin, bilirubin, alkaline phosphatase, gamma glutamyl transferase, alanine and aspartate aminotransfearse, international normalized ratio, antibodies and anti HAV IgG (Architect i2000SR Abbott). HAV immunity was defined as the qualitative presence of HAV IgG antibody (?1.00 reactive) in the serum blood test 6 . All patients with negative HAV IgG were subjected to HAV vaccination after explaining about the potential adverse effects as depicted in figure 1 .

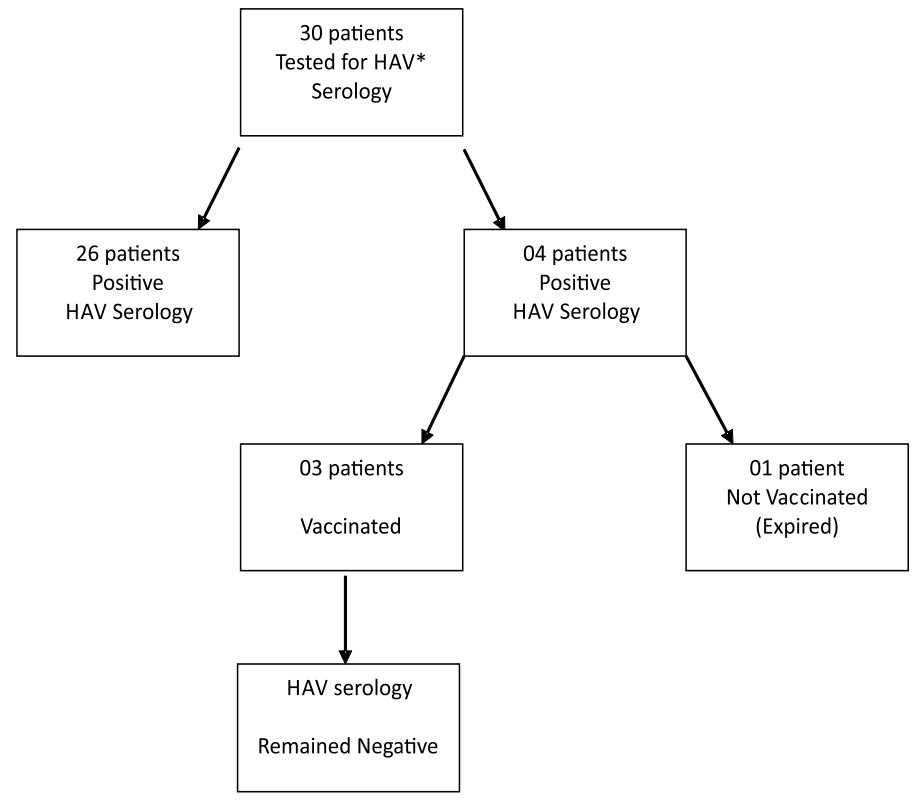

Figure 1: This flowchart represents the induction of participants, testing of $\mathrm{HAV}^{*}$ serology, vaccination and re-testing of serology. ${ }^{*} \mathrm{HAV}$; hepatitis A virus AVAXIM $80 \mathrm{U}$ Inj $0.5 \mathrm{ml}$ (Sanofi Pasteur SA) vaccine was administered intramuscularly (deltoid muscle) for the first dose and second dose after six months. Adverse events related to vaccination were also recorded. We excluded patients with ages $<1$ year or $>15$ years and those whose parents were unable to give consent. This project was approved by institutional ethical review committee. As per institutional policy, the expenses for laboratory and vaccination were borne by the hospital itself (SIUT). Statistical analysis was performed by Statistical Package for Social Sciences (SPSS) version 19.0 (SPSS Inc., Chicago, IL, USA). Frequencies and percentages were computed for categorical variables like gender. Quantitative values like age were presented as mean \pm standard deviation. Patients were stratified into two age groups ( $<5$ and $>5$ years old) to calculate age-related exposure data. A $p$ value of $<0.05$ was considered statistically significant.
Results

A total of 30 pediatric CLD patients with mean age of 9.3 \pm 3.9 years were enrolled. Majority of participants were males $n=19(63.3 \%), 19(63.3 \%)$ of those belonged to city of Karachi, Pakistan while the rest were from the rural areas of Sindh, Pakistan. The baseline demographics and laboratory data is shown in table 1.The severity of liver disease was assessed according to the Child Pugh Turcotte classification. Out of 30 children, $13(43.3 \%), 11(36.7 \%)$ and $6(20 \%)$ were in Child-Pugh class A, B, and C, respectively.

Table 1: Baseline demographics and laboratory data of study population. * HBV along with coinfection $\mathrm{HCV}$ and HDV, ${ }^{* *}$ along with coinfection HBV, ${ }^{* *} \mathrm{AlH}$ with PFIC

\begin{tabular}{|c|c|}
\hline Baseline characteristics & $\mathrm{n}=\mathbf{3 0}(\%)$ \\
\hline $\begin{array}{l}\text { Age in years }(\text { mean } \pm \text { SD }) \\
>5 \text { years } \\
<5 \text { years }\end{array}$ & \begin{tabular}{|l|}
$9.33 \pm 3.87$ \\
$26(86.7)$ \\
$04(13.3)$ \\
\end{tabular} \\
\hline $\begin{array}{l}\text { Gender } \\
\text { Male } \\
\text { Female }\end{array}$ & $\begin{array}{l}19(63.3) \\
11(36.7)\end{array}$ \\
\hline $\begin{array}{l}\text { Place of residence } \\
\text { Urban } \\
\text { Rural } \\
\end{array}$ & $\begin{array}{l}21(70) \\
9(30) \\
\end{array}$ \\
\hline $\begin{array}{l}\text { Ethinicity } \\
\text { Urdu speaking } \\
\text { Sindhi } \\
\text { Punjabi } \\
\text { Pathan } \\
\text { Others } \\
\end{array}$ & $\begin{array}{l}10(33.3) \\
7(23.3) \\
3(10) \\
3(10) \\
7(23.3) \\
\end{array}$ \\
\hline $\begin{array}{l}\text { HAV IgG } \\
<1.00 \text { (non reactive) }\end{array}$ & $\begin{array}{l}5.96 \pm 3.52 \\
26(86.7) \\
04(13.3) \\
\end{array}$ \\
\hline $\begin{array}{l}\text { Severity of liver disease } \\
\text { CTP - A } \\
\text { CTP - B } \\
\text { CTP - C } \\
\end{array}$ & $\begin{array}{l}13(43.3) \\
11(36.7) \\
06(20) \\
\end{array}$ \\
\hline $\begin{array}{l}\text { Source of drinking water } \\
\text { Tap (unboiled) } \\
\text { Boiled } \\
\text { Filtered } \\
\end{array}$ & $\begin{array}{l}20(66.7) \\
05(16.7) \\
05(16.7)\end{array}$ \\
\hline $\begin{array}{l}\text { Hand Washing } \\
\text { Good } \\
\text { Poor } \\
\end{array}$ & $\begin{array}{l}18(60) \\
12(40)\end{array}$ \\
\hline $\begin{array}{l}\text { Street food eating } \\
\text { Yes } \\
\text { No } \\
\end{array}$ & $\begin{array}{l}29(96.7) \\
01(3.3) \\
\end{array}$ \\
\hline Hemoglobin $(\mathrm{g} / \mathrm{dl})$, mean $\pm \mathrm{SD}$ & $9.74 \pm 1.8$ \\
\hline Mean corpuscular volume (fl/cell) & $77.06 \pm 13.02$ \\
\hline Total leukocyte count $\left(10^{3} /\right.$ microliter $)$ & $7.96 \pm 6.22$ \\
\hline Platelets $\left(10^{3} /\right.$ microliter $)$, mean $\pm \mathrm{SD}$ & $117.6 \pm 73.6$ \\
\hline International Normalized Ratio, mean \pm SD & $1.68 \pm 0.9$ \\
\hline Creatinine $(\mathrm{mg} / \mathrm{dl})$, mean $\pm \mathrm{SD}$ & $0.54 \pm 0.64$ \\
\hline Serum Sodium $(\mathrm{mEq} / \mathrm{L})$ & $136.97 \pm 4.08$ \\
\hline Total Bilirubin (mg/dl), mean \pm SD & $3.89 \pm 6.74$ \\
\hline Alanine Aminotransferase $(\mathrm{U} / \mathrm{L})$, mean $\pm \mathrm{SD}$ & $60.83 \pm 47.72$ \\
\hline Aspartate Aminotransferase(U/L),mean $\pm \mathrm{SD}$ & $123.07 \pm 97.8$ \\
\hline Albumin $(\mathrm{g} / \mathrm{dl})$, mean $\pm \mathrm{SD}$ & $2.95 \pm 0.91$ \\
\hline
\end{tabular}

$\mathrm{AlH}$; autoimmune hepatitis, CLD; chronic liver disease, CTP; child turcotte pugh, EHPVO; extrahepatic portal vein obstruction, GSD; glycogen storage disease, HAV; hepatitis A virus, $\mathrm{HBV}$; hepatitis $\mathrm{B}$ virus, $\mathrm{HCV}$; hepatitis $\mathrm{C}$ virus, IgG; immunoglobulin G, PFIC; progressive familial intrahepatic cholestasis, SD; standard deviation Most common cause of CLD was Wilson's disease 
(20\%) followed by extrahepatic portal vein obstruction $(20 \%)$. Majority of patients were using tap (unboiled) water and 29 patients used to consume street food. Proper hand washing was observed in $60 \%$ of the participants. Almost $80 \%$ of participants did not have any family history of liver disease. The overall prevalence of positive HAV serology $(\lg G)$ was $86.7 \%(n=26)$. On further stratification of according to age, the prevalence was $96.15 \%(n=25 / 26)$ in patients older than 5 years of age. Significant association of HAV serology was found only with age $(p=0.04)$ as depicted in table 2 .

Table 2: Association of baseline demographics with hepatitis A serology

\begin{tabular}{|c|c|c|c|c|}
\hline \multirow{2}{*}{\multicolumn{2}{|c|}{ Characteristics }} & \multicolumn{2}{|c|}{ HAV IgG } & \multirow[t]{2}{*}{ P value } \\
\hline & & Reactive & $\begin{array}{c}\text { Non } \\
\text { Reactive }\end{array}$ & \\
\hline Age; $n$ & $\begin{array}{l}>5 \text { years } \\
<5 \text { years }\end{array}$ & $\begin{array}{l}25 \\
1\end{array}$ & $\begin{array}{l}1 \\
3\end{array}$ & 0.04 \\
\hline Gender & $\begin{array}{l}\mathrm{n},(\%) \\
\text { Male } \\
\text { Female }\end{array}$ & $\begin{array}{l}15 \\
11\end{array}$ & $\begin{array}{l}4 \\
0\end{array}$ & 0.27 \\
\hline $\begin{array}{l}\text { Place of } \\
\text { Urba } \\
\text { Rura }\end{array}$ & residence; $\mathrm{n},(\%)$ & $\begin{array}{l}18 \\
8\end{array}$ & $\begin{array}{l}3 \\
1\end{array}$ & 0.81 \\
\hline $\begin{array}{l}\text { Ethinici } \\
\text { Urd } \\
\text { Sind } \\
\text { Punj } \\
\text { Path } \\
\text { Othe }\end{array}$ & $\begin{array}{l}\text { y; n, (\%) } \\
\text { speaking } \\
\text { i } \\
\text { bi } \\
\text { n } \\
\text { s }\end{array}$ & $\begin{array}{l}8 \\
6 \\
3 \\
2 \\
7\end{array}$ & $\begin{array}{l}2 \\
1 \\
0 \\
1 \\
0\end{array}$ & 0.89 \\
\hline $\begin{array}{r}\text { Severity } \\
\text { CTP } \\
\text { CTP } \\
\text { CTP }\end{array}$ & $\begin{array}{l}\text { of liver disease; n, (\%) } \\
-\mathrm{A} \\
-\mathrm{B} \\
-\mathrm{C}\end{array}$ & $\begin{array}{l}11 \\
9 \\
6\end{array}$ & $\begin{array}{l}2 \\
2 \\
0\end{array}$ & 0.55 \\
\hline $\begin{array}{r}\text { Source } \\
\text { Tap } \\
\text { Boil } \\
\text { Filte }\end{array}$ & $\begin{array}{l}\text { f drinking water; } n,(\%) \\
\text { unboiled) } \\
d \\
\text { ed }\end{array}$ & $\begin{array}{l}18 \\
4 \\
4\end{array}$ & $\begin{array}{l}2 \\
1 \\
1\end{array}$ & 0.75 \\
\hline $\begin{array}{l}\text { Hand } \mathrm{W} \\
\text { Goo } \\
\text { Poor }\end{array}$ & shing; $\mathrm{n},(\%)$ & $\begin{array}{l}14 \\
12\end{array}$ & $\begin{array}{l}4 \\
0\end{array}$ & 0.13 \\
\hline $\begin{array}{l}\text { Street } \mathrm{f} \\
\text { Yes } \\
\text { No }\end{array}$ & od eating; $n,(\%)$ & $\begin{array}{l}26 \\
0\end{array}$ & $\begin{array}{l}3 \\
1\end{array}$ & 0.13 \\
\hline
\end{tabular}

CTP; Child Turcotte Pugh, HAV; hepatitis A virus; IgG; immunoglobulin.

Out of 4 seronegative HAV participants, one died before vaccination while the other three; received series of two vaccines 6 months apart and HAV IgG titers were checked at 4 weeks after first and second dose of vaccination. Despite two doses of vaccine satisfactory titer levels could not be achieved as shown in the table 3. After the administration of intramuscular (deltoid) vaccine, local and systemic adverse effects were noted. One of these patients had fever which resolved with paracetamol while another patient had pain at the injection site, which resolved spontaneously, while the third patient remained asymptomatic. No adverse effects were noted after the second dose of the vaccine.
Table 3: Summary of participants screened, vaccinated and their pre and post vaccination titers. *pre vaccination titer, ${ }^{* *}$ titer after 4 weeks of first vaccine dose, ${ }^{* * *}$ titer after 4 weeks of second dose.

\begin{tabular}{|c|c|c|c|c|c|c|c|}
\hline $\begin{array}{l}\text { HAV } \\
\text { Pt. } \\
\text { No. }\end{array}$ & $\begin{array}{l}\text { Age } \\
\text { (year } \\
\text { s) }\end{array}$ & $\begin{array}{l}\text { Gend } \\
\text { er }\end{array}$ & Diagnosis & $\begin{array}{l}\text { HAV } \\
\text { IgG } \\
\text { titer* }\end{array}$ & $\begin{array}{l}\text { Vaccination } \\
2 \text { doses } \\
6 \text { months apart }\end{array}$ & $\begin{array}{l}\text { HAV Ab } \\
\text { Titers*** }\end{array}$ & $\begin{array}{l}\text { HAV } \\
\text { Ab } \\
\text { Titers** } \\
*\end{array}$ \\
\hline 1 & 15 & $\mathrm{M}$ & EHPVO & 0.32 & Given & 1.68 & 0.92 \\
\hline 2 & 2.5 & $\mathrm{M}$ & $\begin{array}{l}\text { BA, } \\
\text { Hepatoblastoma }\end{array}$ & 0.08 & Given & 0.34 & 0.21 \\
\hline 3 & 3 & $\mathrm{M}$ & GSD & 0.16 & Given & 0.13 & 0.39 \\
\hline 4 & 2 & $\mathrm{M}$ & $\begin{array}{l}\text { Biliary } \\
\text { Hypoplasia }\end{array}$ & 0.13 & Expired & ---- & ---- \\
\hline 5 & 6 & $\mathrm{~F}$ & EHPVO & 12.61 & Not Needed & ---- & ---- \\
\hline 6 & 9 & $\mathrm{M}$ & WD & 9.70 & Not Needed & ---- & ---- \\
\hline 7 & 8 & $\mathrm{M}$ & WD & 9.69 & Not Needed & ---- & ---- \\
\hline 8 & 13 & M & $\mathrm{HBV}+\mathrm{CRF}$ & 10.99 & Not Needed & ---- & ---- \\
\hline 9 & 6 & M & PFIC+AIH & 6.15 & Not Needed & \begin{tabular}{|l|}
--- \\
-
\end{tabular} & --- \\
\hline 10 & 7 & $\mathrm{M}$ & EHPVO & 8.96 & Not Needed & ---- & ---- \\
\hline 11 & 13 & $\mathrm{~F}$ & WD & 6.14 & Not Needed & ---- & --- \\
\hline 12 & 6 & $\mathrm{~F}$ & $\begin{array}{l}\text { CRYPTOGENI } \\
\text { C }\end{array}$ & 9.12 & Not Needed & --- & ---- \\
\hline 13 & 10 & $\mathrm{~F}$ & AIH & 6.47 & Not Needed & \begin{tabular}{|l|}
--- \\
\end{tabular} & ---- \\
\hline 14 & 9 & $\mathrm{M}$ & $\begin{array}{l}\text { CRYPTOGENI } \\
\mathrm{C}\end{array}$ & 7.23 & Not Needed & ---- & ---- \\
\hline 15 & 14 & $\mathrm{M}$ & $\mathrm{HBV}+\mathrm{HDV}$ & 9.49 & Not Needed & \begin{tabular}{|l|}
--- \\
\end{tabular} & ---- \\
\hline 16 & 10 & $\mathrm{M}$ & $\mathrm{HBV}+\mathrm{HDV}$ & 11.16 & Not Needed & --- & --- \\
\hline 17 & 3 & $\mathrm{M}$ & $\mathrm{HCV}$ & 3.89 & Not Needed & ---- & ---- \\
\hline 18 & 8 & $\mathrm{M}$ & $\begin{array}{l}\text { CRYPTOGENI } \\
\mathrm{C}\end{array}$ & 17.63 & Not Needed & ---- & ---- \\
\hline 19 & 9 & $\mathrm{~F}$ & WD & 7.50 & Not Needed & $-\cdots$ & --- \\
\hline 20 & 10 & $\mathrm{M}$ & $\mathrm{HBV}+\mathrm{HCV}$ & 1.28 & Not Needed & --- & --- \\
\hline 21 & 5 & $\mathrm{~F}$ & GSD & 3.18 & Not Needed & --- & --- \\
\hline 22 & 11 & $\mathrm{~F}$ & AIH & 5.33 & Not Needed & \begin{tabular}{|l|}
--- \\
\end{tabular} & ---- \\
\hline 23 & 9 & $\mathrm{~F}$ & PFIC & 2.62 & Not Needed & --- & ---- \\
\hline 24 & 7 & $\mathrm{~F}$ & $\begin{array}{l}\text { CRYPTOGENI } \\
\mathrm{C}\end{array}$ & 4.21 & Not Needed & ---- & ---- \\
\hline 25 & 13 & $\mathrm{M}$ & $\mathrm{AIH}$ & 6.23 & Not Needed & ---- & ---- \\
\hline 26 & 7.5 & $\mathrm{M}$ & EHPVO & 4.70 & Not Needed & ---- & ---- \\
\hline 27 & 14 & $\mathrm{~F}$ & WD & 4.35 & Not Needed & --- & ---- \\
\hline 28 & 15 & $\mathrm{M}$ & WD & 6.05 & Not Needed & ---- & ---- \\
\hline 29 & 10 & $\mathrm{~F}$ & $\mathrm{HCV}$ & 5.89 & Not Needed & ---- & --- \\
\hline 30 & 15 & M & $\begin{array}{l}\text { CRYPTOGENI } \\
\text { C }\end{array}$ & 5.51 & Not Needed & --- & --- \\
\hline
\end{tabular}

(HAV IgG ?1.00 reactive, $<1.00$ non-reactive) $(\mathrm{AlH}$; autoimmune hepatitis, EHPVO; extrahepatic portal vein obstruction, HBV; hepatitis B virus, HCV; hepatitis C virus, HDV; Hepatitis D virus, CRF; chronic renal failure, , BA; biliary atresia, GSD; glycogen storage disease, PFIC; progressive familial intrahepatic cholestasis, WD Wilson's disease)

Discussion

Superadded HAV Infection in patients with chronic liver disease (CLD) can induce acute hepatic insult resulting into sudden decompensation of the liver disease, acute on chronic liver disease, acute on chronic liver failure (ACLF) and/or death. This depends upon the severity of acute injury and baseline functional status of liver. According to Lal $\mathrm{J}$ et al. 7, superimposed acute viral hepatitis is responsible for $>50 \%$ of the ACLF cases in children. The most effective way for prevention of HAV infection in children with CLD is HAV vaccination. Efficacy of HAV vaccine declines with the progression of liver disease and if possible, should ideally be given before the development of cirrhosis in such patients. But due to the high prevalence of HAV in the developing nations, targeted vaccination strategy is advised. 8 This same strategy was employed by us and we tested 30 
pediatric patients with CLD for HAV IgG and ended up vaccinating those with negative test results.

In our study, $86.7 \%$ children with CLD had positive serology against HAV infection. This is similar to the $85 \%$ exposure rates seen in children with CLD from Egypt and India and is contrary to Srivastava A et al.8, where approximately $75 \%$ of less than 5 -year-old children were unexposed to HAV. The incidence of HAV exposure varies significantly in those under the age of 5 year and those above the age of 5 years. This range varies from $25 \%$ to $86.7 \%$ respectively. This difference may be attributed to the fact that since most children start going to school at the age of 3 years and thus are at increased risk to acquire water/food borne illnesses. But interestingly in our studied population, 29 participants used to consume street food often but its association with HAV seropositivity was statistically not significant $(p=0.13)$

Prevention of food borne illnesses can be done by the use of clean (boiled) water and by implementing proper hand washing techniques. Contrary to this, in our study we did not find these risk factors as statistically significant with $p$ values of 0.75 and 0.13 respectively. Moreover, HAV vaccination has been shown to be safe and effective in CLD patients irrespective of its etiology. 9 However the vaccine efficacy is inversely related to the severity of liver disease, so it is better to vaccinate early, before the development of decompensated liver disease.

Superimposed hepatitis A, B, and E infections account for $52 \%$ to $97 \%$ of ACLD or ACLF cases in pediatric CLD patients. The overall outcome is worse in ACLF than ACLD pediatric CLD patients (mortality $59 \%$ vs $11 \%$, $\mathrm{P}=0.001) .10$ Thus, it is of paramount importance to ensure early vaccination of such patients against HAV and therefore we tested all of them and only $4(13.3 \%)$ were found to be seronegative for HAV. One of them died just after the initiation of study due to his illness while the other three received a series of two vaccines 6 months apart and HAV IgG titers were checked at 4 weeks after first and second dose of vaccination. Despite two doses of vaccine; satisfactory titers could not be achieved as shown in table 3. Out of three who were vaccinated, one was diagnosed with biliary atresia complicated by hepatoblastoma, second one had glycogen storage disease and the third one had extrahepatic portal vein obstruction (EHPVO). Only one patient achieved positive HAV serology 4 weeks after the first dose but all of them had negative serology 4 weeks after the second dose. Post vaccination seroconversion rates vary depending upon the severity of liver disease. In Child class B or C cirrhosis, it is nearly $37 \%$ and $66 \%$ after first and second dose respectively. 11 Apart from advanced liver disease, increasing age, a higher BMI, and the presence of diabetes mellitus are associated with a decline in response to HAV vaccination. 12

Post vaccination adverse effects were also noted. According to the American Academy of Family
Physicians, side effects related to HAV vaccination are rare, and these include tenderness, headache, and malaise. 13 One had fever which resolved with paracetamol and another patient had pain at the injection site which was resolved spontaneously while the third patient remained asymptomatic. No adverse effects were noted after the second dose.

Like most studies our study has also few limitations. It is a single center study with small sample size that would limit to extrapolate the present study findings on pediatric CLD patients. Due to the high prevalence of the disease our findings would be applicable only to those countries with similar endemicity for hepatitis $A$.

\section{Conclusion}

In conclusion, this is the first study in pediatric patients with CLD to evaluate exposure to HAV in Pakistan. We observed high HAV seroprevalence in children of $>5$ years of age. Our study showed universal HAV vaccination would not be cost-effective for children with CLD, however, selective vaccination in younger children (1-5 years) can be offered. Early vaccination is advisable in such patients as advanced liver disease may not achieve adequate titers.

\section{References}

1 Ahmadi Vasmehjani A, Javeshghani D, Baharlou $R$, Shayestehpour M, Mousavinasab SD, Joharinia $\mathrm{N}$ et al. Hepatitis $\mathrm{A}$ infection in patients with chronic viral liver disease: a cross-sectional study in Jahrom, Iran. Epidemiol Infect. 2015 Feb;143(3):534-9. doi: 10.1017/S0950 268814000806.

2 Bosan A, Qureshi H, Bile KM, Ahmad I, Hafiz R. A review of hepatitis viral infections in Pakistan. $J$ Pak Med Assoc. 2010 Dec;60(12):1045-58.

3 Mirzaei J, Ziaee M, Farsad SA, Fereydooni M, Anani Sarab G, Rezvani Khorashad MR. Vaccination Against Hepatitis A for Hemophilic Patients: Is It Necessary? Hepat Mon. 2016 Apr 5;16(4):e37447. doi: 10.5812/hepatmon.37447.

4 Joshi N, Rao S, Kumar A, Patil S, Rani S. Hepatitis A vaccination in chronic liver disease: is it really required in a tropical country like India? Indian J Med Microbiol. 2007 Apr;25(2):137-9.

5 Fiore AE, Wasley A, Bell BP. Prevention of hepatitis $A$ through active or passive immunization: recommendations of the Advisory Committee on Immunization Practices (ACIP). MMWR Recomm Rep. 2006; 55(RR-7):1-23.

6 Ramirez JC, Ackerman K, Strain SC, Ahmed ST, de Los Santos MJ, Sears D. Hepatitis A and B screening and vaccination rates among patients with chronic liver disease. Hum Vaccin Immunother. 2016;12(1):64-9. doi: 10.1080/21645515.2015.1068484.

7 Lal J, Thapa BR, Rawal P, et al. Predictors of outcome in acute-onchronic- liver failure in children. Hepatol Int 2011;5:693-7. doi: 10.1007/s12072-010-9217-z. 
8 Srivastava A, Mathias A, Yachha SK, Agarwal J, Aggarwal R. Need for immunization against hepatotropic viruses in children with chronic liver disease. J Pediatr Gastroenterol Nutr. 2014 Sep;59(3):393-7. doi: 10.1097/MPG.000000 0000000437.

9 Reiss G, Keeffe EB. Review article: hepatitis vaccination in patients with chronic liver disease. Aliment Pharmacol Ther 2004;19:715-27. DOI:10.1111/j.1365-2036.2004.01906.x

10 Jagadisan B, Srivastava A, Yachha SK, et al. Acute on chronic liver disease in children from the developing world: recognition and prognosis. J Pediatr Gastroenterol Nutr 2012;54:77-82. doi: 10.1097/MPG.0b013e318228d7da.

11 Leise MD, Talwalkar JA. Immunizations in chronic liver disease: what should be done and what is the evidence. Curr Gastroenterol Rep. 2013 Jan;15(1):300. doi: 10.1007/s11894-0120300-6.

12 Kramer ES, Hofmann C, Smith PG, Shiffman $\mathrm{ML}$, Sterling RK. Response to hepatitis A and B vaccine alone or in combination in patients with chronic hepatitis $C$ virus and advanced fibrosis. Dig Dis Sci. 2009 Sep;54(9):2016-25.

13 Matheny SC, Kingery JE. Hepatitis A. Am Fam Physician. 2012;86(11):1027-1034. 